\title{
Gestão do tempo e organização diária
}

DOI: dx.doi.org/10.18616/nrm 13

Jacks Soratto Jalila Musa Rahman Maria Ines da Rosa

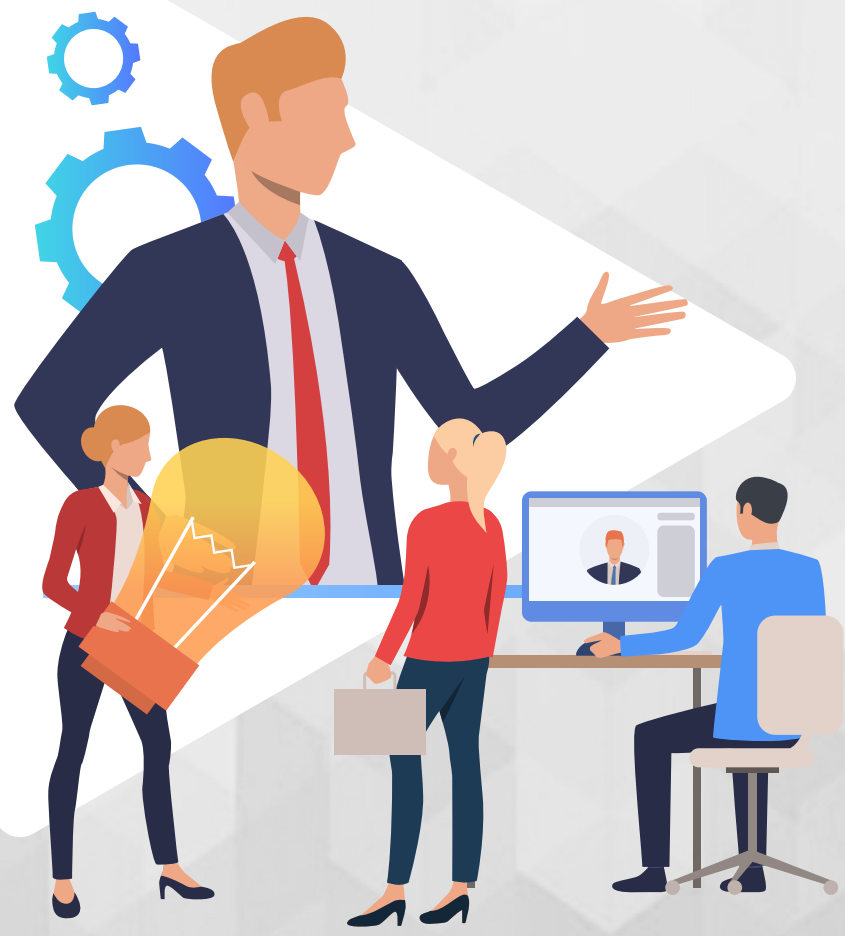


Em tempos de pandemia e de isolamento, tornaram-se essenciais os trabalhos home-office. Em outros tempos, isso poderia significar liberdade, entretanto, agora, apresenta novos desafios, pois existe um acúmulo de funções domésticas, o cuidado com os filhos, os animais de estimação, entre outros, que exigem um tempo extra.

É comum a perda da noção temporal no distanciamento social em decorrência da mudança drástica da rotina habitual. Nesse sentido, o gerenciamento do tempo é importante para termos melhores resultados e também para oportunizarmos mais tempo livre para ações diversas, sejam elas de interesse individual ou coletivo.

\section{SALVAMENTO E ORGANIZAÇÃO DE ARQUIVOS}

Objetivo: oportunizar acesso a documentos, proporcionando mais tranquilidade na certeza de que você terá tudo o que precisa referente a seu trabalho, estudo ou documentos pessoais de forma muito rápida.

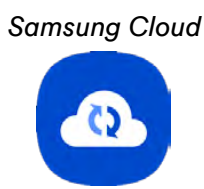

Baixe aqui lcloud

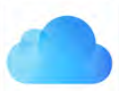

Baixe aqui
Google Drive

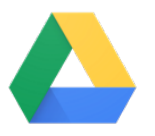

Baixe aqui

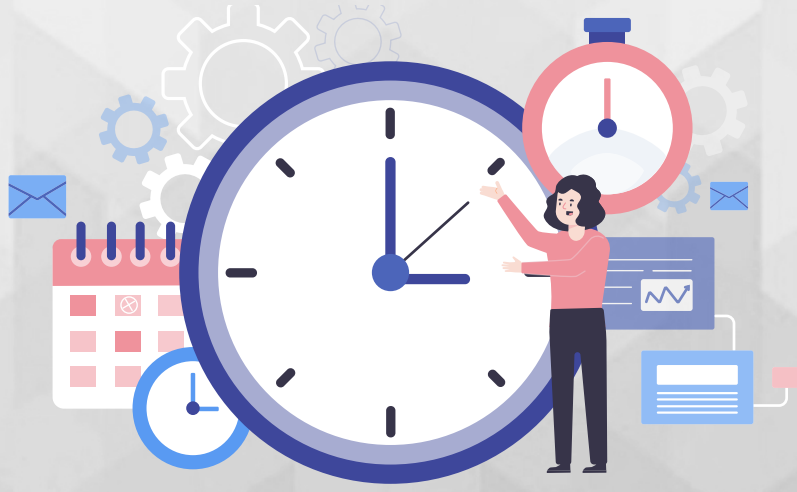




\section{DICAS PARA O APROVEITAMENTO DO TEMPO}

1. Ter uma agenda de atividades: preferencialmente, substitua as anotações em papel pelo bloco de notas e a agenda no calendário do seu celular.

2. Estabelecer prioridades: elaborar o planejamento semanal das atividades que serão realizadas.

3. Atividades não programadas: se acaso ocorrerem, tente finalizar primeiro aquele seu compromisso que estava pré-agendado.

4. Fuja das distrações: estabeleça um período do dia para visualizar as notícias gerais e acessar as redes sociais.

5. Aprenda a dizer não: faça isso com aquelas atividades que não são urgentes e que podem acumular funções.

6. Seja objetivo nas reuniões: defina pautas e estabeleça um tempo para o término.

7. Delegue funções: aos filhos, colegas e/ou funcionários, dividindo as tarefas.

8. Fortaleça a qualidade de vida: organize um tempo para atividades físicas e espiritualidade.

9. Mantenha o sono adequado: estabeleça um horário regular para dormir e para acordar.

Para manter o foco e não ficar distraído por causa de seu celular, sugerimos o seguinte aplicativo:

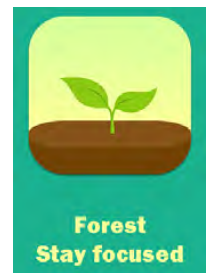

Fonte: SEEKRTECH (2020). 